\title{
Some properties of Tomas cheese and identification of lactic acid bacteria isolated from Tomas cheese
}

\author{
*Fatma Çoşkun ${ }^{1}$, Duygu Korucu ${ }^{2}$

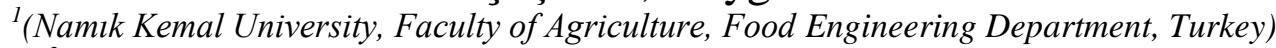 \\ ${ }^{2}$ (Research and Application Center of Scientific and Technological Research, Turkey)
}

\begin{abstract}
In this research, some properties of 16 Tomas cheese samples, collected from different areas in the Elazig province in Turkey, were investigated. The dry matter, fat, salt, ash, protein, titratable acidity, ripening index and $\mathrm{pH}$ changed between 39.70-46.01\%; 16.20-21.56\%; 3.31-4.95\%; 4.41-6.90\%;11.80-23.83\%; 0.9$1.8 \% ; 13.18-42.04 \% ; 4.5-6.03$, respectively. The total aerobic mesophilic bacteria, yeast-mould and lactic acid bacteria(on MRS and M17 agar) count changed between 6.67-9.01 log cfu/g; 5.30-8.39 log cfu/g; 6.25-8.91 log cfu/g; 6.56- $9.01 \mathrm{log} c f u / g$, respectively. Coliforms were determined as $<1$ in all the samples. In the classification was 6 isolates(30\%) Lactobacillus paracasei subsp. paracasei, 5 isolates(25\%) Lactobacillus brevis, 4 isolates(20\%) Lactobacillus plantarum, 2 isolates(10\%) Lactobacillus collinoides, 2 isolates(10\%) Lactobacillus curvatus subsp. curvatus and one of the isolates(5\%) Lactobacillus salivarius. According to the results of the identification of coccal isolates, 16 of the isolates(66.6\%) were identified as Enterococcus faecium and 8 of isolates(33.3\%) were identified as Lactococcus lactis subsp. lactis.
\end{abstract}

Keywords: Tomas cheese, local cheese, lactic acid bacteria

\section{Introduct $\square$ on}

Cheese has a history of approximately 8000-9000 years. It arose between the Euphrates and Tigris rivers [1]. That area is part of Iran, Iraq and Turkey[2]. Today, cheese type in the world are known to be more than 4000[3]. Aroma and texture of these cheeses are different from each other. Some of these cheeses are consumed as fresh and some cheeses is consumed after a ripening period under certain conditions [4]. In Turkey, 193 varieties of cheese are produced [5]. Tomas cheese is traditionally produced in Eastern Anatolia region in Turkey. Tomas is a type of Tulum cheese (brynza). First, yogurt produced from sheep and goat's milk is subjected to churning. Later, buttermilk obtained from yoghurt is heated in order to obtain skim-milk cheese. The skim-milk cheese is placed in cloth bags and filtered. Later, it is salted and enriched by adding ingredients such as butter, cream and yoghurt. The mixture is poured and pressed into a leather tulum. Then the mix is matured for 1-3 month. After ripening, it is kneaded and again poured and pressed into a leather tulum. After these operations, the cheese is ready for consumption. Tomas cheese does not have any production standards. Because of small family plant production, its chemical and microbiological quality completely related to the skills of the people engaged in the production. In particular, mold spores infecting the clot in the production environment lead to the formation of different colors, flavors and aromas in the cheese during ripening [6]. Tomas cheese, like all other traditional cheeses, is sometimes manufactured in scant hygienic conditions using different methods. The natural microflora affects the organoleptic properties and the safety of the product. The studies conducted on Tomas cheese are insufficient. This study was performed to determine some properties of the Tomas cheese samples. Tomas cheese isolates can be potentially used during the commercial production of Tomas cheese or other fermented dairy products. This contribute to a continuity of cultural heritage and economic development.

\section{Material and Method}

The Tomas cheese samples were gathered from different households in the Elazig province of Turkey.

The samples were analyzed in duplicate for determination of acidity, $\mathrm{pH}$, dry matter, fat, ash, salt, total nitrogen and water soluble nitrogen. The dry matter content was detected by drying of samples at $100 \pm 2^{\circ} \mathrm{C}$ for 4 $\mathrm{h}$ [7]. The fat content was determined through butyrometric method[8]. To determine the ash content, portions $(2 \mathrm{~g})$ of the cheese samples were turned into ash in a porcelain crucible at $550^{\circ} \mathrm{C}[8]$. The $\mathrm{pH}$ value was measured using a digital $\mathrm{pH}$ meter(Hanna Instruments $\mathrm{pH} 211$ microprocessor $\mathrm{pH}$ meter) [8]. The titratable acidity(lactic acid, \%) and the salt was detected by the titration method [9]. The total nitrogen was analyzed through the Kjeldahl method practiced by Gripon et al. [10]. In the protein content calculation was used Kjeldahl Nx6.38 as formul. The water soluble nitrogen (WSN) was detected through the Kjeldahl method [11]. The nitrogen content in the extracted cheese was regarded as ripening index and stated as a percentage of the total nitrogen (WSN/TN, \%) [12]. 
Total aerobic mesophilic bacteria counts were examined using plate count agar (PCA). Incubation was performed at $30^{\circ} \mathrm{C}$ for $48 \mathrm{~h}$. Yeast and mould counts were examined using potato dextrose agar (PDA). Incubation was continued for 5 days at $25^{\circ} \mathrm{C}[13,14]$. de Man Rogosa Sharpe (MRS) agar (anaerobically for 72 $\mathrm{h}$ at $30 \pm 1^{\circ} \mathrm{C}$ ) [15] and M17 agar (aerobically for $48 \mathrm{~h}$ at $30 \pm 1^{\circ} \mathrm{C}$ ) were used for lactic acid bacteria counts [16]. Violet red bile (VRB) agar was used to determine coliform group bacteria counts and incubation was continued for $24 \mathrm{~h}$ at $37^{\circ} \mathrm{C}$ [14].

The cell morphology of all lactobacilli isolates was observed using phase contrast microscopy. The isolates were tested for gram reaction. The catalase reaction was determined by adding $3 \% \mathrm{H}_{2} \mathrm{O}_{2}$ on the isolates. All lactobacilli isolates, for the gas production from the glucose was grown in the MRS broth. The salt tolerance was observed in MRS broth supplemented with the addition of $2 \%$ and $4 \% \mathrm{NaCl}$. A growth rate at $15^{\circ} \mathrm{C}$ or $45^{\circ}$ $\mathrm{C}$ was tested in the MRS broth. For growth rate, incubation was continued for three days. The hydrolysis of the arginine was examined in the MRS broth. MRS broth was containing $0.2 \%(\mathrm{v} / \mathrm{v})$ sodium citrate replacing the ammonium citrate and $0.3 \%$ of arginine, and not containing glucose and meat extract. Nessler's reagent was used to determine of ammonia [17]. Fermentation or assimilation of various carbon sources was tested. For the lactobacilli was used API 50 CHL (BioMérieux SA. Marcy l'Etoile. France). API 20 STREP was used for lactococci.

The differences between the 16 Tomas cheese samples were analyzed using SPSS 15 as statistical software (SPSS Corporation, Chicago, IL, USA). Multiple comparisons were made between means by ANOVA techniques. Duncan's test were used to compare means [18].

\section{Results and Discussions}

The physicochemical properties of the Tomas cheese samples are indicated in Table 1. According to the results of the statistical evaluation, remarkable differences between the chemical properties of cheese samples were observed. The minimum, maximum and mean ripening index values were $13.18 \%, 42.04 \%$ and $23.37 \%$, respectively. The microbiological properties of Tomas cheese samples are indicated in Table 2 . The coliform group bacteria counts were determined as $<1 \mathrm{log} \mathrm{cfu} / \mathrm{gin}$ all the samples. Forty-four lactic acid bacteria from 16 Tomas cheese samples were isolated and identified. Nearly $45.5 \%$ of lactic acid bacteria were Lactobacillus (growing on MRS agar). Other lactic acid bacteria (54.5\%) identified were Enterococcus and Lactococcus (growing on M17 agar). In the classification,6 isolates (13.6\%) were identified asLactobacillus paracasei subsp. paracasei; 5 isolates(11.4\%) were identified asLactobacillus brevis; 4 isolates $(9.1 \%)$ were identified asLactobacillus plantarum;2 isolates(4.5\%)were identified asLactobacillus collinoides; 2 isolates(4.5\%) Lactobacilluscurvatus subsp. curvatuswere identified asand one of the isolates(2.3\%) was identified asLactobacillus salivarius. In the classification of coccal isolates, 16 of the isolates(36.4\%) were identified as Enterococcus faecium and 8 of isolates(18.2\%) identified were Lactococcus lactis subsp. Lactis. Biochemical properties of lactic acid bacteria (Lactobacillus)are indicated in Table 3.

Table 1. Some physicochemical properties of Tomas cheese samples and their statistical evaluations

\begin{tabular}{|c|c|c|c|c|c|c|c|}
\hline 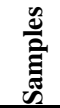 & $\underset{(\%)}{\text { Dry matter }}$ & $\begin{array}{l}\text { Fat } \\
(\%)\end{array}$ & $\begin{array}{l}\text { Ash } \\
(\%)\end{array}$ & $\begin{array}{l}\text { Salt } \\
(\%)\end{array}$ & $\begin{array}{l}\text { Protein } \\
(\%)\end{array}$ & $\begin{array}{l}\text { Acidity } \\
(\%)\end{array}$ & pH \\
\hline 1 & $43.95 \pm 0.03^{\mathrm{c}}$ & $16.20 \pm 0.07^{\mathrm{h}}$ & $6.55 \pm 0.11^{b}$ & $3.98 \pm 0.24^{\mathrm{e}}$ & $19.80 \pm 0.01^{\mathrm{c}}$ & $1.3 \pm 0.05^{\mathrm{ef}}$ & $4.75 \pm 0.15^{\text {bcd }}$ \\
\hline 2 & $39.70 \pm 0.10^{i}$ & $19.46 \pm 0.35^{\mathrm{c}}$ & $5.14 \pm 0.23^{f}$ & $4.27 \pm 0.28^{\mathrm{d}}$ & $13.89 \pm 0.25^{1}$ & $1.1 \pm 0.05^{\mathrm{g}}$ & $4.63 \pm 0.05^{\text {de }}$ \\
\hline 3 & $46.01 \pm 0.10^{\mathrm{a}}$ & $15.65 \pm 0.71^{1}$ & $5.20 \pm 0.29^{\mathrm{ef}}$ & $3.91 \pm 0.14^{\mathrm{e}}$ & $23.83 \pm 0.08^{\mathrm{a}}$ & $1.2 \pm 0.10^{\mathrm{fg}}$ & $4.76 \pm 0.01^{\text {bed }}$ \\
\hline 4 & $43.39 \pm 0.04^{\text {de }}$ & $18.50 \pm 0.35^{\mathrm{f}}$ & $6.25 \pm 0.17^{\mathrm{c}}$ & $4.62 \pm 0.08^{\mathrm{bc}}$ & $17.00 \pm 0.02^{f}$ & $1.2 \pm 0.10^{\mathrm{fg}}$ & $4.79 \pm 0.01^{\mathrm{bcd}}$ \\
\hline 5 & $40.24 \pm 0.09^{1}$ & $21.25 \pm 0.06^{\mathrm{b}}$ & $6.55 \pm 0.11^{b}$ & $4.95 \pm 0.22^{\mathrm{a}}$ & $11.80 \pm 0.01^{\mathrm{j}}$ & $1.7 \pm 0.05^{\mathrm{ab}}$ & $4.62 \pm 0.06^{\mathrm{de}}$ \\
\hline 6 & $43.35 \pm 0.02^{\mathrm{de}}$ & $19.01 \pm 0.41^{\mathrm{d}}$ & $6.37 \pm 0.05^{\mathrm{bc}}$ & $4.53 \pm 0.13^{\mathrm{c}}$ & $16.98 \pm 0.03^{\mathrm{f}}$ & $1.6 \pm 0.05^{\mathrm{cd}}$ & $4.78 \pm 0.03^{\mathrm{bcd}}$ \\
\hline 7 & $41.52 \pm 0.03^{\mathrm{h}}$ & $19.54 \pm 0.35^{\mathrm{c}}$ & $5.79 \pm 0.05^{\mathrm{d}}$ & $4.65 \pm 0.47^{\mathrm{bc}}$ & $14.56 \pm 0.08^{\mathrm{h}}$ & $1.5 \pm 0.05^{\mathrm{cd}}$ & $4.89 \pm 0.005^{\mathrm{bc}}$ \\
\hline 8 & $41.98 \pm 0.10^{\mathrm{g}}$ & $18.05 \pm 0.71^{g}$ & $6.90 \pm 0.11^{\mathrm{a}}$ & $4.51 \pm 0.25^{\mathrm{c}}$ & $16.05 \pm 0.50^{g}$ & $1.5 \pm 0.01^{\mathrm{cd}}$ & $4.87 \pm 0.005^{\mathrm{bc}}$ \\
\hline 9 & $43.03 \pm 0.12^{\mathrm{e}}$ & $18.58 \pm 0.08^{\mathrm{ef}}$ & $6.43 \pm 0.11^{\mathrm{bc}}$ & $4.94 \pm 0.12^{\mathrm{a}}$ & $17.08 \pm 0.35^{\mathrm{f}}$ & $1.4 \pm 0.01^{\mathrm{de}}$ & $4.51 \pm 0.04^{\mathrm{e}}$ \\
\hline 10 & $41.74 \pm 0.15^{\text {gh }}$ & $21.05 \pm 0.06^{b}$ & $6.49 \pm 0.05^{\mathrm{bc}}$ & $4.95 \pm 0.37^{\mathrm{a}}$ & $12.87 \pm 0.25^{\mathrm{i}}$ & $0.9 \pm 0.10^{\mathrm{h}}$ & $6.03 \pm 0.02^{\mathrm{a}}$ \\
\hline 11 & $44.81 \pm 0.21^{b}$ & $18.45 \pm 0.25^{\mathrm{f}}$ & $5.44 \pm 0.05^{\mathrm{e}}$ & $4.74 \pm 0.11^{b}$ & $20.38 \pm 0.09^{b}$ & $1.8 \pm 0.05^{\mathrm{a}}$ & $4.73 \pm 0.05^{\mathrm{bcd}}$ \\
\hline 12 & $42.42 \pm 0.07^{\mathrm{f}}$ & $19.68 \pm 0.05^{\mathrm{c}}$ & $4.41 \pm 0.02^{g}$ & $3.31 \pm 0.83^{\mathrm{f}}$ & $17.36 \pm 0.06^{\mathrm{e}}$ & $1.5 \pm 0.10^{\mathrm{cd}}$ & $4.94 \pm 0.02^{b}$ \\
\hline 13 & $43.54 \pm 0.08^{\mathrm{d}}$ & $18.99 \pm 0.08^{\mathrm{d}}$ & $5.79 \pm 0.05^{\mathrm{d}}$ & $4.61 \pm 0.17^{\mathrm{bc}}$ & $17.68 \pm 0.25^{\mathrm{d}}$ & $1.6 \pm 0.15^{\mathrm{bc}}$ & $4.79 \pm 0.06^{\mathrm{bcd}}$ \\
\hline 14 & $43.09 \pm 0.02^{\mathrm{e}}$ & $18.78 \pm 0.07^{\mathrm{de}}$ & $6.37 \pm 0.05^{\text {bc }}$ & $4.65 \pm 0.49^{\text {bc }}$ & $16.98 \pm 0.09^{f}$ & $1.6 \pm 0.10^{\mathrm{bc}}$ & $4.90 \pm 0.02^{\mathrm{b}}$ \\
\hline 15 & $40.19 \pm 0.10^{1}$ & $19.46 \pm 0.02^{\mathrm{c}}$ & $5.03 \pm 0.11^{f}$ & $3.85 \pm 0.45^{\mathrm{e}}$ & $14.34 \pm 0.08^{\mathrm{h}}$ & $1.8 \pm 0.05^{\mathrm{a}}$ & $4.79 \pm 0.05^{\mathrm{bcd}}$ \\
\hline 16 & $40.35 \pm 0.04^{1}$ & $21.56 \pm 0.21^{\mathrm{a}}$ & $5.79 \pm 0.05^{\mathrm{d}}$ & $4.26 \pm 0.30^{d}$ & $12.02 \pm 0.05^{j}$ & $1.5 \pm 0.10^{\mathrm{cd}}$ & $4.68 \pm 0.02^{\text {cde }}$ \\
\hline
\end{tabular}

$\mathrm{a}, \mathrm{b}, \mathrm{c}, \mathrm{d}, \mathrm{e}, \mathrm{f}, \mathrm{g}, \mathrm{h}, \mathrm{i}, \mathrm{i}, \mathrm{j}$; There is no difference between group means with the same letter.

The reason for remarkable differences between the properties of cheese samples may be the absence of any production standard and production recipe for Tomas cheese. Besides, the heat treatment applied to the milk and milk type may cause the main difference between cheese samples. The manufacturing steps is very effective 
on the quality and properties of the final cheese. The texture and flavor of cheese develops with the progress of ripening, which characterise the different cheese varieties. The biochemical changes that take place during ripening are very complex. Starter cultures and enzymes of starter cultures, non starter lactic acid bacteria and their enzymes also participate in the ripening process [19].

Table 2. Some microbiological properties of Tomas cheese samples

\begin{tabular}{|c|c|c|c|c|c|}
\hline$\frac{\mathscr{e}}{\overline{\tilde{E}}}$ & $\begin{array}{c}\text { Total aerobic mesophilic } \\
\text { bacteria } \\
\text { (log cfu/g) }\end{array}$ & $\begin{array}{c}\text { Yeast and } \\
\text { moulds } \\
(\log \text { cfu/g) }\end{array}$ & $\begin{array}{c}\text { Coliform } \\
\text { bacteria } \\
\text { (log cfu/g) }\end{array}$ & $\begin{array}{l}\text { Lactic acid bacteria } \\
\text { (on MRS agar) } \\
\text { (log cfu/g) }\end{array}$ & $\begin{array}{l}\text { Lactic acid bacteria } \\
\text { (on M17 agar) } \\
\text { (log cfu/g) }\end{array}$ \\
\hline 1 & $7.65 \pm 0.04$ & $7.72 \pm 0.06$ & $<1$ & $7.85 \pm 0.15$ & $7.87 \pm 0.23$ \\
\hline 2 & $8.53 \pm 0.25$ & $8.39 \pm 0.04$ & $<1$ & $8.50 \pm 0.12$ & $8.59 \pm 0.01$ \\
\hline 3 & $7.93 \pm 0.47$ & $8.16 \pm 0.09$ & $<1$ & $7.99 \pm 0.08$ & $8.09 \pm 0.08$ \\
\hline 4 & $7.67 \pm 0,06$ & $7.53 \pm 0.06$ & $<1$ & $7.48 \pm 0.02$ & $7.64 \pm 0.18$ \\
\hline 5 & $6.73 \pm 0.03$ & $6.25 \pm 0.24$ & $<1$ & $6.25 \pm 0.24$ & $7.25 \pm 0.24$ \\
\hline 6 & $7.28 \pm 0.44$ & $7.69 \pm 0.08$ & $<1$ & $7.56 \pm 0.07$ & $7.63 \pm 0.05$ \\
\hline 7 & $9.01 \pm 0.01$ & $8.60 \pm 0.01$ & $<1$ & $8.91 \pm 0.02$ & $9.01 \pm 0.004$ \\
\hline 8 & $7.15 \pm 0.15$ & $6.71 \pm 0.15$ & $<1$ & $6.95 \pm 0.24$ & $7.15 \pm 0.15$ \\
\hline 9 & $6.77 \pm 0.07$ & $6.58 \pm 0.05$ & $<1$ & $6.99 \pm 0.08$ & $6.86 \pm 0.24$ \\
\hline 10 & $8.10 \pm 0.06$ & $8.14 \pm 0.05$ & $<1$ & $7.99 \pm 0.04$ & $8.37 \pm 0.11$ \\
\hline 11 & $6.73 \pm 0.19$ & $5.30 \pm 0.30$ & $<1$ & $6.71 \pm 0.03$ & $7.22 \pm 0.02$ \\
\hline 12 & $6.67 \pm 0.16$ & $6.87 \pm 0.02$ & $<1$ & $6.43 \pm 0.14$ & $6.56 \pm 0.17$ \\
\hline 13 & $7.47 \pm 0.12$ & $7.07 \pm 0.13$ & $<1$ & $7.25 \pm 0.24$ & $7.13 \pm 0.01$ \\
\hline 14 & $8.12 \pm 0.11$ & $7.90 \pm 0.07$ & $<1$ & $8.31 \pm 0.02$ & $8.43 \pm 0.03$ \\
\hline 15 & $8.17 \pm 0.05$ & $6.45 \pm 0.26$ & $<1$ & $6.73 \pm 0.03$ & $8.81 \pm 0.20$ \\
\hline 16 & $7.70 \pm 0.19$ & $7.13 \pm 0.20$ & $<1$ & $7.59 \pm 0.01$ & $7.32 \pm 0.16$ \\
\hline
\end{tabular}

In this study, differences between the acidity of cheese samples were observed. According to estimates, the reason for difference between acidity values difference in ripening periods of cheeses and materials. Because, the acidity is associated with the ripening periods of cheeses. This is also true for $\mathrm{pH}$ values. In the study conducted by AteşandPatır[20] the $\mathrm{pH}$ of the Tulum cheese samples was decreased continuously during the ripening period. The $\mathrm{pH}$ values was determined as 5.84 and 5.46, respectively at the first day and at the ninety day as higher from $\mathrm{pH}$ values determined in this study. The acidity was 0.67 at the beginning of ripening. The acidity was 0.92 at the end of the ninety day as lower from $\mathrm{pH}$ values determined in this study. The reason for this difference may be the difference in the production methods. The duration of the ripening period of cheeses samples used in this study could have lasted longer. In this research, the reason for differences between the fat amounts of cheese samples may be the difference in the amount of cream added. Furthermore, ripening period may have influenced the amount of fat. The oxidation or lipolysis can degrade fat of cheese. The fat in cheese is important for the sensation and cheese flavor [21]. The amount of salt varied depending on the choice of manufacturers. Additionally, the difference in the ripening period may be reason for the difference in the amount of salt. Many researchers indicated that steady increase in the amount of salt in the progress of ripening $[22,23]$. Ateşand Patır[20] determined that the amount of salt continuously increased during the ripening period. The amount of salt of Tulum cheese in their study was (as mean values) $4.17 \%$ and $4.81 \%$, respectively at the first day and the ninety day. The amount of salt of Tulum cheeses in this study is similar to their findings.

A total of 20 Tomas cheese samples were analyzed by Kurtetal.[24], and the acidity (SH), moisture, dry matter, protein, fat, non fat dry matter, fat in dry matter, salt and ash contents (as mean values) were 102.5, $52.5 \%, 47.49 \%, 22.26 \%, 18.13 \%, 29.37 \%, 38.18 \%, 3.05 \%, 3.42 \%$, respectively. Thedry matter and protein contents are higher than the values obtained in this work. The salt and ash content is lower. The fat content is similar in both studies. The reason for difference between researches may be difference in ripening periods of cheeses and materials. Gündüz[25]produced Tomas cheese in laboratory conditions using Penicillium roqueforti Thom. Samples were used as experimental materials after the production, in the first, second, third, and fourth months. The total aerobic mesophilic bacteria,lactic acid bacteria, proteolitic bacteria, Candida lipolytica, $P$. roqueforti, Lactobacillus plantarum, Lactobacillus bulgaricus, Streptococcus lactis, Streptococcus cremoris and S. thermophiles count in the fourth month (as mean value) were determined as $7.36 \times 10^{7}, 5.82 \times 10^{7}, 1.54 \times 10^{7}$, $5.5 \times 10^{7}, 1,47 \times 10^{9}$ (excluding the sample that had not been inoculated with starter culture), $20 \times 10^{6}, 1.18 \times 10^{7}$, $1.26 \times 10^{7}, 0.84 \times 10^{7}, 0.54 \times 10^{7} \mathrm{cfu} / \mathrm{g}$, respectively. The fat in dry matter, degree of ripening, acidity (lactic acid) and $\mathrm{pH}$ (as mean values) were determined as $49.91 \%, 47.45 \%, 2.098$, and 6.08 , respectively. The results of this study were lower than the results determined by Gündüz.

Karin Kaymagi cheese is similar to Tulum cheese and usually manufactured from sheep's milk. It is pressed into the rumen and matured. Its fat content is very high. Turgutetal.[26] were identified Lactobacillus strains from Karin Kaymagi cheese. L. plantarum type 1 and type 2, L. brevis type 1 and type 3, L. acidophilus type 3, L. delbrueckii subsp. delbrueckii and L. fermentum were identified as $47.56 \%, 21.9 \%, 9.75 \%, 1.97 \%$ and 
$2.43 \%$, respectively. $24.4 \%$ of bacterial flora consisted of L.mesenteroides subsp. mesenteroides/dextranicum type 2 isolates. L. plantarum and L. brevis are in the dominant cultures in both studies. The mean dry matter, fat, and protein contents of the samples were found as $74.66 \%, 43.36 \%$ and $25.51 \%$, respectively. The values obtained in our study are lower than these values. Because Karin Kaymagi cheese made from sheep's milk. In their study, the total aerobic mesophilic bacteria, lactic acid bacteria and yeast and mold counts were found as 6.477-8.17 $\log \mathrm{cfu} / \mathrm{g}, 6.649-8.041 \mathrm{log} \mathrm{cfu} / \mathrm{g}$ and 3.556-5.308 $\mathrm{log} \mathrm{cfu} / \mathrm{g}$, respectively. S. aureus and coliform group bacteria counts were determined under the acceptable limit $(<10 \log \mathrm{cfu} / \mathrm{g})$. Except for the yeast mold count and S.aureus, these counts are similar to the numbers obtained in our study. Çakmakç1etal. [27] analyzed 13 samples of Karin Kaymagi cheese. The acidity (lactic acid), dry matter, fat, non fat dry matter, fat in dry matter, protein, water soluble protein, ash, salt, salt in dry matter and degree of ripening(as mean values) were determined as $1.01 \%, 69.10 \%, 39 \%, 30.10 \%, 57.18 \%, 19.01 \%, 3.77 \%, 6.19 \%, 4.36 \%, 6.15 \%$ and $19.27 \%$, respectively. The results of this study were different from the results determined by Çakmakçıetal. The reason for this could be the difference in process or materials.

Table 3. Biochemical properties of lactic acid bacteria (Lactobacillus) (+= positive result $\quad-=$ negative result)

\begin{tabular}{|c|c|c|c|c|c|c|c|c|c|}
\hline 产 & $\begin{array}{l}\text { Growth } \\
\text { at } 15^{\circ} \mathrm{C}\end{array}$ & $\begin{array}{c}\text { Growt } \\
\text { h at } \\
45^{\circ} \mathrm{C} \\
\end{array}$ & $\begin{array}{c}\text { Gas } \\
\text { production } \\
\text { from glucose }\end{array}$ & $\begin{array}{c}\text { Growth } \\
\text { in } 2 \% \\
\mathrm{NaCl}\end{array}$ & $\begin{array}{c}\text { Growth } \\
\text { in } 4 \% \\
\mathrm{NaCl}\end{array}$ & $\begin{array}{c}\mathrm{NH}_{3} \\
\text { production } \\
\text { from arginine }\end{array}$ & $\begin{array}{c}\text { Catalas } \\
\text { e test }\end{array}$ & $\begin{array}{l}\text { Gram's } \\
\text { staining }\end{array}$ & API 50 CHL \\
\hline TB09 & - & - & + & + & + & - & - & + & Lb. brevis \\
\hline TB13 & + & - & - & + & + & + & - & + & Lb. plantarum \\
\hline TB15 & - & - & - & + & + & + & - & + & Lb. brevis \\
\hline TB16 & + & - & + & + & - & - & - & + & Lb. collinoides \\
\hline TB18 & + & - & - & + & + & + & - & + & $\begin{array}{c}\text { Lb. paracasei subsp. } \\
\text { paracasei }\end{array}$ \\
\hline TB19 & - & - & - & + & + & + & - & + & $\begin{array}{c}\text { Lb.curvatussubsp. } \\
\text { curvatus }\end{array}$ \\
\hline TB20 & + & - & - & + & + & - & - & + & $\begin{array}{c}\text { Lb. paracasei subsp. } \\
\text { paracasei }\end{array}$ \\
\hline TB24 & - & - & + & + & - & + & - & + & Lb. salivarius \\
\hline TB27 & + & - & - & + & + & - & - & + & $\begin{array}{c}\text { Lb. paracasei subsp. } \\
\text { paracasei }\end{array}$ \\
\hline TB29 & + & - & - & + & + & + & - & + & Lb. plantarum \\
\hline TB34 & - & - & + & + & + & + & - & + & Lb. brevis \\
\hline TB39 & - & - & - & + & + & - & - & + & $\begin{array}{l}\text { Lb. curvatus subsp. } \\
\text { curvatus }\end{array}$ \\
\hline TB41 & - & - & - & + & + & - & - & + & Lb. brevis \\
\hline TB42 & + & - & - & + & + & - & - & + & Lb. plantarum \\
\hline TB43 & + & - & - & + & + & + & - & + & $\begin{array}{c}\text { Lb. paracasei subsp. } \\
\text { paracasei }\end{array}$ \\
\hline TB48 & + & - & + & + & - & - & - & + & Lb. collinoides \\
\hline TB53 & + & - & + & + & + & + & - & + & Lb. brevis \\
\hline TB57 & - & - & - & + & + & + & - & + & $\begin{array}{c}\text { Lb. paracasei subsp. } \\
\text { paracasei }\end{array}$ \\
\hline TB60 & + & - & - & + & + & - & - & + & $\begin{array}{c}\text { Lb. paracasei subsp. } \\
\text { paracasei }\end{array}$ \\
\hline TB66 & - & - & - & + & + & + & - & + & Lb. plantarum \\
\hline
\end{tabular}

In study conducted by AteşandPatır[20] on Tulum cheeses, the total aerobic mesophilic bacteria count was described between $1.1 \times 10^{8}-7.7 \times 10^{8} \mathrm{cfu} / \mathrm{g}$ after the ripening process. The yeast and mould count was between $3.4 \times 10^{4}-2.6 \times 10^{7} \mathrm{cfu} / \mathrm{g}$. The coliform group bacteria was detected as $<10 \mathrm{cfu} / \mathrm{g}$ in one sample on the fifteenth day of ripening, as <10 cfu/gin all samples in the ninetieth day. The total aerobic mesophilic bacteria, yeast-mould, and coliform group bacteria counts obtained in this study is similar to counts determined by Ateş and Patır[20]. Coliform group microorganisms are continually decrease during ripening period. They may be lost completely disappeared at different times according to the type of cheese. $\mathrm{pH}$ values continually decrease during ripening

[28]. In this study, it may be the reason for determined as < $1 \log \mathrm{cfu} / \mathrm{gof}$ coliform group bacteria count.

Kılıçand Gönç [29] isolated and identified Lactobacillus, Enterococcus and Lactococcus fromIzmir Tulum cheeses. They approved the use of Lactococcus lactis subsp. lactis, Lactococcus lactissubsp. cremoris, L. casei and E. faecalis in the production of Izmir Tulum cheese. Öneretal.[30] determined that lactobacilli constitute the dominant flora of in Tulum cheese. However, Lactococcus was determined as $15.8 \%$ in cheese flora. In the study conducted by Öksüztepeetal.[31], L. lactis subsp. lactis, L. mesenteroides subsp. cremoris and L. lactis subsp. cremoris played very important roles in the ripening of Savak Tulum cheese as the major species. The study conducted by BüyükyörükandSoyutemiz [32]was done to isolate strains (L. lactis subsp. lactis and L. lactis subsp. cremoris)belonging to the Lactococcus genus in İzmir Tulum cheese. L. lactis subsp. lactis were identified as 18 of the isolates(20\%). Eleven isolates (12.8\%) were L. lactis subsp. cremoris. In this study, L. lactis subsp. lactis was identified $18.2 \%$ (8 of isolates). 


\section{Conclusion}

Consequently, in this study, strains and species of several Lactobacillus, Lactococcus and Enterococcus species have been isolated, identified. These findings are similar to the findings of other studies. Although Tomas cheese is a type of Tulum cheese, is different from Tulum cheese in terms of materials used for production. The characterization in this study will lead the selection of suitable strains to be used in the production of Tomas cheese. These species may also be used in the production of various fermented dairy products. This may be an improvement for the dairy industry. Investigation and identification of traditional foods contribute to a continuity of cultural heritage and economic development.

\section{Acknowledgement}

The authors gratefully acknowledge the NKUBAP (Namik Kemal University Scientific Research Project Fund) for providing the funding for this study.

\section{References}

[1]. F.V.Kosikowski andV.V. Mistry,Cheese and fermented milk foods. Vol. 1. Westport, CT, 06880: F.V. KOSIKOWSKI, LLC,1997.

[2]. C.Koçak and A.Gürsel, New aspects in Tulum cheese technology,In: Proceedings of the 5th Egyptian Conference for Dairy Science and Technology, 19-20 October, Egypt, 1992, 15-23.

[3]. J.L.Steele andG.Ünlü,Impact of lactic acid bacteria on cheese flavor development,Food Technology,46, 1992, 128-135.

[4]. G.Elmalı andV. Uylaşer, Geleneksel Gıdalardan Çeçil Peynirinin Üretimi ve Özellikleri,Uludă Üniversitesi Ziraat Fakültesi Dergisi,26(1), 2012, 83-92.

[5]. A.Çetinkaya,Yöresel Peynirlerimiz, 1. Baskı, Academic Book Production, Kars, Turkey, 2005

[6]. H.H. Gündüz,Tomas Cheese.In: Proceedings of the 1st International Symposium on Traditional Foods from Adriatic to Caucasus, 15-17 April, Tekirdag, Turkey, 2010, 68-71.

[7]. Anonymous,Peynir ve İşlenmiş peynir-Toplam KatıMadde MiktarıTayini (Referans Metod), Türk Standartları Enstitüsü (TS 5311), Ankara, Turkey, 1987.

[8]. A. Kurt,S. Çakmakçı andA. Çağlar,Süt ve Mamülleri Muayene ve Analiz MetotlarıRehberi, Atatürk Üniversitesi Ziraat Fakültesi Yayın No:18, Erzurum, Turkey, 1996.

[9]. Anonymous, Beyaz Peynir, Türk Standartları Enstitüsü (TS 591), Ankara, Turkey,1989.

[10]. J.C.Gripon, M.J. Desmazeaud, D.J.Bars andL. Bergere,Etude du rôle des micro-organismes et des enzymes au cours de la maturation des fromages. II. - Influence de la présure commercial,Lait, 55(548), 1975, 502-516.

[11]. M. Demirci andH.H. Gündüz, Peynir Analizleri.Süt Teknoloğunun El Kitabı.3. Baskı. Hasad Yayıncılık, Istanbul, Turkey, 2000.

[12]. C. Alais,Science du lait - principes des techniques laitieres. (4th ed) Sepaic, Paris, 1984.

[13]. FDA,Bacteriological Analytical Manual (8th edn.), Rev. A. AOAC International, Gaithersburg. VA,USA,1998.

[14]. R.T.Marshall,Standart Methods for The Examination of Dairy Products (16th edn.), American Public Health Association, Washington, DC, 1992.

[15]. J. Baumgart,Mikrobiologische Untersuchung von Lebensmitteln 3. Auflage, Behr's Hamburg, 1993.

[16]. S.E.Gilliland andH.S. Kim,Effect of viable starter culture bacteria in yoghurt on lactose utilization in humans,Journal of Dairy Science,67, 1984, 1-6.

[17]. U.Schilllinger and F.K. Lucke,Identification of lactobacilli from meat and meat products. Food Microbiology,4, 1987, 199-208.

[18]. M.I.Soysal, Biometrinin Prensipleri. Trakya Üniversitesi, Ziraat Fakültesi Yayınları, Yayın No: 95, Tekirdag, Turkey, 1992.

[19]. P.F.Fox, T.P. O'connor, P.L.H. McSweeney, T.P. Guinee andN.M. O'brien, Cheese: Physical, chemical, biochemical and nutritional aspects. Advances in Food and Nutrition Research,39, 1996, 163-328.

[20]. G.Ateş andB. Patır,Starter Kültürlü Tulum Peynirinin Olgunlaşması Sırasında Duyusal, Kimyasal ve Mikrobiyolojik Niteliklerinde Meydana Gelen Değișimler Üzerine Araștırmalar,Fırat Üniversitesi Sağllk Bilimleri Dergisi, 15(1),2001, 45-56.

[21]. P.Molimard andH.E. Spinnler,Compounds involved in the flavor of surface mold-ripened,Journal of Dairy Science, 79, 1996, 169184.

[22]. M.Arıcı andO. Şimşek,Kültür Kullanımının Tulum Peynirinin Duyusal, Fiziksel-Kimyasal ve Mikrobiyolojik Özellikleri Üzerine Etkisi,Glda,16(1), 1991, 53-62.

[23]. G.Y Öztürk andB. Nazlı, Deneysel olarak enfekte edilen sütle yapılan tulum peynirlerinde Brucella melitensis'in mevcudiyeti üzerine çalışmalar,Pendik Veteriner Mikrobiyoloji Enstitüsü Dergisi, 27, 1996, 123 - 142.

[24]. A.Kurt, H.H. Gündüz andM. Demirci,Tomas Peyniri Üzerine Araștırmalar,Atatürk Üniversitesi Ziraat Fakültesi Dergisi, 10(1-2), 1979, 37-39.

[25]. H.H Gündüz,Tomas Peyniri: I. Tomas Peynirinin Doğal Mikroflorası, Glda,7(5), 1982, 227-230.

[26]. T.Turgut andA. Erdogan, Identification of lactobacilli isolated from Karın Kaymagi cheese, Kafkas Üniversitesi Veteriner Fakültesi Dergisi,18(2), 2012, 209-213.

[27]. S.Çakmakçı,M. Şenol andA. Çağlar Karın Kaymağı Peynirinin Üretim Tekniği ve Bazı Fiziksel ve Kimyasal Özellikleri, Gıda,20 (4), 1995, 199-203.

[28]. B.Patır,G. Ateş andA.H. Dinçoğlu, Geleneksel yöntemle üretilen tulum peynirinin olgunlasması sırasında meydana gelen mikrobiyolojik ve kimyasal degisimler üzerine araştırmalar,Fırat Üniversitesi Sağllk Bilimleri Dergisi, 15(1), 2001, 1-8.

[29]. S.Kılıç andS. Gönç, İzmir Tulum peynirinin olgunlaşmasında rol oynayan mikroorganizma gruplarının belirlenmesi üzerine bir araştırma,Ege Üniversitesi Ziraat Fakültesi Dergisi, 29, 1992, 71-78.

[30]. Z.Öner, O. Sağdıç andB. Şimşek,Lactic acid bacteria profiles and tyramine and tryptamine contents of Turkish tulum cheeses, European Food Research and Technology,219, 2004, 455-459.

[31]. G.Öksuztepe,B. Patır andM. Çalıkoğlu,Identification and distribution of lactic acid bacteria during the ripening of Savak Tulum cheese,Turkish Journal of Veterinary Animal Sciences, 29, 2005, 873-879.

[32]. S.Büyükyörük andG.E. Soyutemiz,Geleneksel olarak üretilmiș İzmir Tulum peynirinden Lactococcus lactis (Lactococcus lactis alttür lactis ve alttür cremoris) suşlarının izolasyonu, fenotipik ve moleküler teknikler ile identifikasyonu ,Erciyes Üniversitesi Veteriner Fakültesi Dergisi, 7(2), 2010, 81-87. 